Published in "Studies in Communication Sciences" 13(1), 2013, 3-14

which should be cited to refer to this work

\title{
International public relations: A synopsis of German-speaking and Anglo-American research approaches
}

\author{
Diana Ingenhoff*, Christopher Ruehl \\ University of Fribourg, Department of Media and Communication Research, Boulevard de Pérolles 90, CH 1700 Fribourg, Switzerland
}

\section{Introduction: the emergence of international PR as a field of research}

One could probably not describe the developments the field of research has undergone in the last twenty years more concisely than Bardhan and Weaver (2011, p. 1) when they stated, "Public Relations has gone global." In this paper, however, we follow a more differentiated approach to delineating the newly rising field of international public relations (PR). Our aim is to systemize and analyze the efforts, approaches and findings spawned by German-language and Anglo-American research. In doing so, we will explore what the terms "global" and "international" really mean for PR; illustrate the conditions under which the field has developed besides "traditional PR"; and discuss the major methods and models used for studies in the international arena. As international PR applies to different cultural contexts, we will take a closer look at different concepts of culture (Hofstede, 1980; House, Hanges, Javidan, Dorfman, \& Gupta, 2004) and discuss implications associated with various ways of looking at culture in research - an aspect widely neglected thus far.

Taking the 21st century's internationalized environment as a starting point for our analysis, we need to acknowledge that processes of globalization have brought forth the international integration of a multitude of social (sub) areas. Moreover, far-reaching technological advances in the area of communication media and

\footnotetext{
* Corresponding author. Tel.: +41 263008383.

E-mail addresses: diana.ingenhoff@unifr.ch (D. Ingenhoff), christopher.ruehl@unifr.ch (C. Ruehl).
}

communication channels have accelerated globalization over the last two decades (Taylor, 2001, p. 73; Szondi, 2009, p. 123). Today, organizational activities are no longer limited by national borders. Organizations expand their activities from their home countries across different nation states. Accordingly, organizations increasingly become multi-national (Curtin \& Gaither, 2007, p. 56) and face new challenges posed by internationally linked stakeholders. In addition, organizations need to take into account the different conditions prevalent in different countries, such as political and technological environments or media systems.

As of today, scholars have not yet managed to develop commonly accepted definitions, models and methods adequate for extensive studies of PR taking the underlying complexities of PR in the multinational organizations into full account (Andres, 2004, p.189; Curtin \& Gaither, 2007, p. 3; Sievert \& Porter, 2009, p. 2). This gap has led to a recent state of knowledge in PR research described as "fragmentary and rudimentary" (Klare, 2010, p. 73). The same applies to the practices of organizations which have not yet developed a shared understanding of how the challenges posed by a multitude of cultures in various countries can be dealt with. ${ }^{1}$

The internationalization of communication management and PR as a separate research area is still young and was only identified as a "hot topic" in the mid-90s (Culbertson, 1996), especially in

\footnotetext{
1 The recent argument between Google and the Chinese government allows for a concrete example to illustrate this point. In 2010, the Chinese government threatened the search engine operator to deprive their website operating license, if Google did not obey to Chinese censorship rules when prompting search engine results (Barboza \& Stone, 2010).
} 
German-speaking and Anglo-American countries (Curtin \& Gaither, 2007, p. 8). This has to do with the fact that the development of PR is a phenomenon of Western societies, in which market capitalism was introduced early (Miller \& Dinan, 2003). Characteristic of existing research to date are efforts to fructify existing PR theories internationally. However, such efforts reach their limits in regard to new global realities, necessitating a repositioning of PR theory (Bardhan \& Weaver, 2011, p. 1).

\section{Defining international PR research and its perspectives}

When systemizing existing conceptualization of international PR research, we can distinguish between three main approaches (see also Andres \& Bentele, 2008, p. 595; Zaharna, 2000, p. 87):

(1) internationally oriented PR practices of organizations, i.e. international PR

(2) international comparative PR research focusing primarily on descriptions and comparisons of national occupational fields

(3) international PR of nation states, i.e. nation PR

While international $P R$ is concerned with the study of PR practices and the structures and processes of internationally operating organizations or companies, the aim of comparative $P R$ is to reveal differences and similarities between the countries investigated, taking cultural norms as well as social, political and economic environments into account. The third area of research focuses on the international PR efforts of nations and governments or other national interest groups, respectively, to positively influence a country's image abroad (Kunczik, 1997, p. 12). Nation PR is also known as public diplomacy (Karten, 2008). However, the question remains: Which perspectives on definitions can be identified to discriminate between the three areas?

In German-language research, international PR is closely aligned to the definition of "traditional" PR, in which the central aim of PR is the management of an organization's relationships with internal and external stakeholders. This definition mainly becomes extended with an international perspective (Andres \& Bentele, 2008, p. 595; Klare, 2010, p. 74). Huck (2007, p. 892) coins the term international corporate communications, i.e. country and crosscultural communication management including all internal and external communication activities of any company to build up or to maintain relationships with stakeholders in different nations or cultures with the ultimate goal of building and expanding a globally coherent reputation.

We can find similar terminology in the Anglo-American world, also resembling the basic assumptions about PR. In an early definition, Wilcox, Ault, and Agee (1989, p. 395) ${ }^{2}$ describe international PR as "the planned and organized effort of a company, institution, or government to establish mutually beneficial relations with publics of other nations." Similarly, Grunig defined international PR as "a broad perspective that will allow [practitioners] to work in many countries - or to work collaboratively with many nations" (Grunig, 1992, p. 23). Wakefield (2007, p. 355) sees international PR as "a multinational program that has certain coordination between headquarters and various countries where offices and/or publics are located, and that carries potential consequences or results in more than one country" (Wakefield, 1997, p. 355).

Quite early Botan (1992, p. 157) and later Zaharna (2001) noted that international PR should always be understood as cross-cultural PR, since communication processes cannot escape country-specific characteristics and contexts. Banks (2000, p. 20)

\footnotetext{
2 This definition also remains unchanged in the eighth edition of the miscellany in 2007 .
}

approves this premise and speaks of multicultural $P R$ in the international environment. According to his definition "multicultural public relations is the management of formal communication between organizations and their publics to create and maintain communities of interest and action that favour the organization, taking full account of the normal human variation in the systems of meaning by which groups understand and enact their everyday lives." In summary, international PR is primarily defined as country border-crossing communication activity of companies or any other type of organization.

From the above we can delineate studies of international comparative $P R$, which dominate the research especially in Anglo-American countries. However, distinguishing comparative PR research is not always easy since such research is often addressed as "international public relations” (e.g. Sriramesh \& Verčič, 2001, 2003, 2009a) or "global PR" (Freitag \& Stokes, 2009). Comparative PR describes PR in different countries. Its goal, according to Culbertson and Chen (1996, p. 2), is to explore "more or less universal problems that challenge many or all nations, and to search for generic principles that apply widely." Therefore, comparative analyzes of national PR practices in different countries aim to detect commonalities and differences from which external environmental variables expected to influence PR practices can be derived.

The field of public diplomacy, in which governments are seen as international PR actors, has gained very little attention, yet (Kunczik, 2003, p. 399; Signitzer \& Coombs, 1992; Szondi, 2009, p. 145). Public diplomacy is defined by Delaney (1968) as "the way in which both government and private individuals and groups influence directly or indirectly those public attitudes and opinions which bear directly on another government's foreign policy decision." He argues that the transitions of international PR by governments and other organizations are fluid. This is why Kunczik (1992, p. 339) puts international PR on a level with nation PR a few years later; an idea similarly expressed by Pasquier, Weiss, and Yersin (2009, p. 16). Curtin and Gaither (2007, p. 9) even differentiate further and describe the targeted PR efforts of governments (primarily from developing and emerging countries) to achieve national and international goals as "nation building" activities. An additional perspective is offered by Szondi (2005, p. 208) who describes public diplomacy as only one element in a "pantheon of international PR for nation states." According to him, what differentiates public diplomacy from the other elements in the pantheon (i.e. destination branding, cultural relations, country branding and perception management), is that the communicator of PR needs to be the government of a specific country, whereas for example cultural relations can emanate from non-profit cultural associations mostly concerned with language, art etc. (Szondi, 2005, p. 213).

\section{International PR strategies}

Regardless of whether we look at the PR strategies of countries or multinational corporations, or whether country-specific PR practices are at the center of our attention, one can see that PR was primarily extended to international PR to account for cultural components. Important criteria affecting international PR theorizing go back to research on intercultural communication. Within that field, we can basically distinguish between three research approaches toward the influence of culture on communication, which were later transferred to the study of organizations and international public relations: (1) the culture-specific approach, (2) the culture-free approach, and (3) the hybrid model.

The so-called culture-specific approach examines the specific characteristics of a particular culture. In organization and management research, the corresponding research questions mostly center around how a country's culture affects organizational behavior (Tayeb, 1988) and in turn, how organizations need to 
adapt to culture-specific features. Many studies in the field of comparative $P R$ fall under the culture-specific paradigm, since they analyze PR in one country and look for differences in the national practices on a global level (Culbertson, 1996; e.g. for SouthEast Asia: Sriramesh, 1992; Sriramesh, 1996, for the middle East: Kruckeberg, 1996; for Africa: Pratt, 1985).

The "culture-free" approach is the counter pole to the aforementioned approach. In the culture-free approach research focuses on identifying similarities across cultures (e.g. Hall, 1959, 1976). Transferring such insights to management research, one assumes that culture does not determine organizational behavior. Therefore, transnationally operating organizations can adopt a uniform global strategy (Heller, 1988). Within the culture-free approach of $\mathrm{PR}$, one consequently looks for similarities and generic principles which apply to PR practices worldwide, such as the functions, roles and goals of PR (Botan, 1992), or static variations in the political, social or economic system as well as within the infrastructure of the country (van Leuven \& Pratt, 1996).

From an extreme pole point-of-view, the first two approaches characterize the tension zone between universalism (similarities and shared aspects of a culture) and relativism (differences distinguishing one culture from another), also described as "standardization" vs. "specialization" (Müller, 1992), "localization" (Kanso, 1992), or "adaption” (Szondi, 2009, p. 127).

The third approach describes a combination of the above culture-specific and culture-free approaches: the hybrid model. Within the area of culture-oriented management research, Brinkerhoff and Ingle (1989) developed generic variables which comprise the overarching goals and issues of an organization which can be standardized across cultures. They combine these variables with specific variables which differ within the culture of an organization's home country and the host country and therefore need to be adapted to the particular needs of the local society.

The acknowledgements from cultural and management research have been transferred to PR especially in regard to the degree of organizational adaptation of their communication strategies in the international arena. In regard to the many challenges posed by international public relations, it seems that the hybrid strategy has become the favored PR strategy in the meantime (Verčič, Grunig, \& Grunig, 1996), also known as "glocalisation." The latter term is especially used to describe the tension area between global standardization of communication management and differentiation of local communication tools and strategies (e.g. Huck, 2007; Huck-Sandhu, 2011). In PR research, and particularly within the Anglo-American field of excellence, such findings were enhanced by Grunig's (2006, p. 170) development of "a theory of generic principles and specific applications that falls midway between an ethnocentric theory (that public relations is the same everywhere) and a polycentric theory (that public relations is different everywhere)."

In the ethnocentric model, PR ideologies present at organizational headquarters dominate PR practices (Botan, 1992, p. 150). Thus, the management of PR resembles the local implementation of decisions made by global management teams and does not, or only very limitedly, consider cultural or other differences between the home country and other countries in which an organization is active (Kinzer \& Bohn, 1985). Botan (1992, p. 152) calls this a trans-border perspective for $P R$.

In contrast the polycentric model accounts for global sociocultural differences: "[In] the polycentric model, [...] host country PR practitioners exercise a high degree of autonomy" (Botan, 1992, p. 151). Within this view PR is developed locally with regard to national conditions and cultural characteristics of different countries individually on site, even though central communication goals are set by global headquarters' communication departments (Botan, 1992, p. 151). Nevertheless, a strong focus on environmen- tal factors in different countries poses the risk of only partially achieving the organization's overall communication goals.

In German-language research Andres and Bentele (2008) address the challenges of international PR in the process of globalization in a very similar way. They distinguish between internal and external aspects of international PR. Internal international $P R$ encompasses thematic aspects such as corporate culture, intercultural management or interactions with employees from different cultural and/or religious backgrounds in the organizational environment (Andres \& Bentele, 2008, p. 595). Among the external aspects are strategic variables, such as the PR strategy which can assume four shapes:

(1) a centralized strategy in which all PR is organized at organizational headquarters;

(2) an internationally cooperative strategy in which international PR is developed at headquarters in cooperation with other parts of the company;

(3) an umbrella strategy in which local adjustments are made at the level of national subsidiaries according to strategic communication guidelines, and finally;

(4) a decentralized strategy in which subsidiaries in other countries are free to design and implement their own national PR strategies.

The aforementioned discussions illustrate that the center of interest in international public relations revolves around the possibilities and limitations of standardized international PR and thus, necessary local adjustments which need to be made in a host county (Klare, 2010, p. 75; Lützler, 2007, p. 134).

Building on Banks (2000), Botan (1992), Huck (2004, p. 18) and Klare (2010, p. 75), we can illustrate international PR strategies of organizations, as shown in Fig. 1, on a continuum between complete standardization on the one hand and complete differentiation on the other hand. With regard to Banks (2000), we put more emphasis on potential multi-culturalism than Huck (2004, p. 18) and Klare (2010, p. 75) did. Switzerland provides a good example in illustrating how four different (language) cultures can exist within one country. Similar characteristics can also be found in Belgium, Italy and Spain in Europe as well as Canada in North America. Thus, it is imperative that international PR is adapted in each country with respect to the number of existing cultures $\left(\operatorname{CULT}_{n}\right)$, if not at least to a generally identifiable national culture $\left(\mathrm{CULT}_{1}\right)$.

\section{State of research on international PR}

Back in the 1970s and 1980s we could find isolated pioneer studies about the internationalization of PR, both in German-speaking (Dornis, 1971) and Anglo-American countries (Barovick, 1982). Nevertheless, a systematic and sustained engagement with international PR research did not start until the 1990s. Some researchers attribute this trend to the liberalization of Soviet communist states from the end of the 1980s on, which brought along the need for international PR communication to develop these new markets (Howard, 1997, p. 27; Sriramesh, 2003, p. xxvi). The following systematization of present models and studies of international PR is closely aligned to the differentiation of internationally oriented $P R$ of organizations, international comparative $P R$ research and international public relations of nations.

\subsection{Internationally oriented $P R$ of multinational organizations}

While Botan (1992, p. 152) posits that most organizations follow an ethnocentric approach to PR in Anglo-American research, it has been widely acknowledged during the 1990s that the standard- 


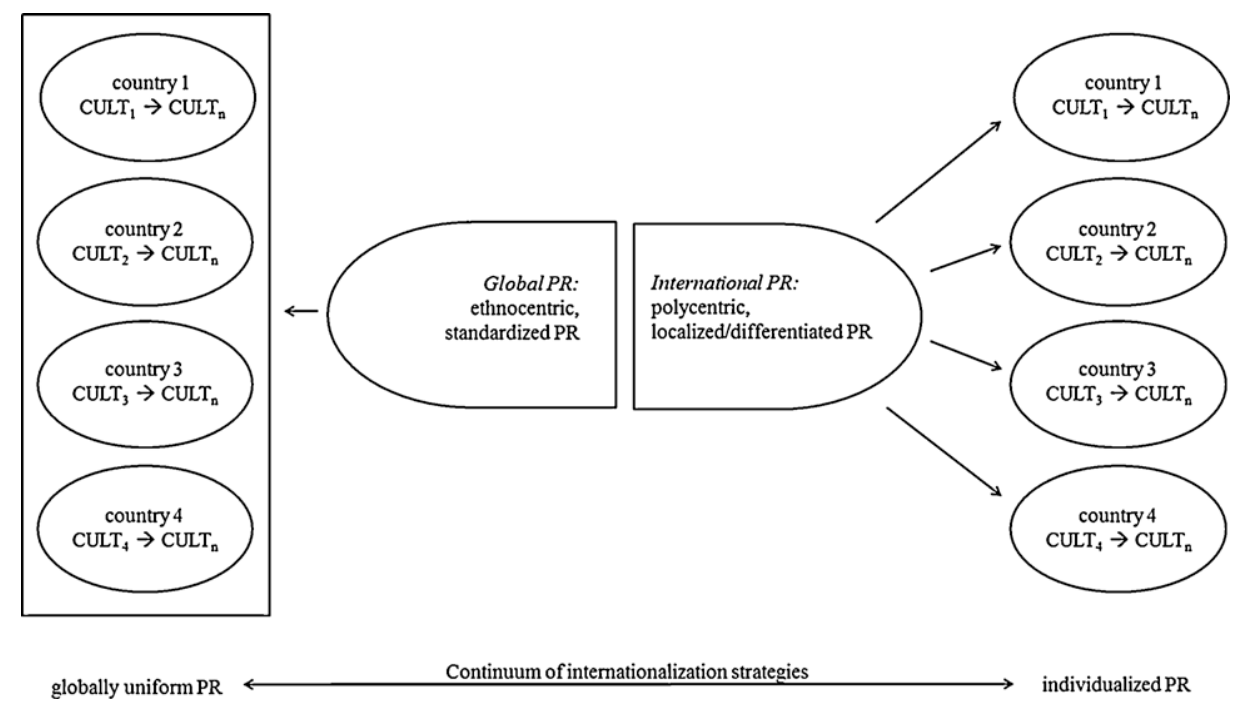

Fig. 1. International PR strategies according to Huck (2004, p. 18) and Klare (2010, p. 75).

ization of PR faces strict limits (Klare, 2010, p. 77ff). Therefore, the focus of the German-language research has revolved around exploring the limits of international standardization and diversification of PR communication between parent companies and their subsidiaries in more detail (Klare, 2010, p. 16). For the AngloAmerican world, Culbertson (1996, p. 2) includes many other types of internationally operating organizations into the research field, such as political organizations like the UN or organizations from the cultural sector. One example of research which follows Culbertson's understanding of international organizations is Tak's (1999) examination of the European Commission's PR practices in the judgment of international foreign correspondents. However, Tak focuses primarily on the correspondents' information relationships with the EU Commission, and is less concerned with questions about the Commission's polycentrism or standardization efforts with PR in regard to correspondents' cultural diversity.

One of the first comprehensive examinations of international PR in German-speaking research is the work of Dornis (1971). He describes internationally operating companies as special types of companies, and their development of national PR strategies to achieve specific objectives in host countries as the main problem of international PR (Dornis, 1971, p. 49). Dornis concludes that corporate decision-making processes in the international environment are more difficult to take than on the national level and notes that international PR depicts new territory for most organizations. Thus, companies, at that time, had not yet managed to establish routines which significantly guide their decision-making processes. Therefore, Dornis (1971, pp. 47-59) pledges for a complete international orientation of all PR efforts, a suggestion which was pursued in research only forty years later. We will address such approaches in more detail in the following section.

\subsubsection{Studies on international PR strategically planned and executed by global headquarters in home countries}

The vast number of German-language publications focus on the issue of overall international PR efforts organized from the headquarters in their home countries (Klare, 2010, p. 79). A similar approach can be found in Henneke (1998), who describes international PR from a constructivist perspective as a tool for the construction of reality in the information society. Kleebinder (1995) pursues a marketing-centered approach, in which he works out a framework of factors for international PR and examines their influence on the processes of public opinion forming in Europe. He concludes that international communication which respects the customs, values and traditions of the host country can be seen as a strategic success factor in the global information society (Kleebinder, 1995, p. 253). Consequently, Kleebinder puts more emphasis on the importance of national localization of PR in terms of adjusting and considering cultural characteristics (language, etc.). Nevertheless, his ideas remain largely ethnocentric.

In their compilation of strategies and concepts of various communication professionals in international markets, Johanssen and Steger (2001) underline the practical uselessness of rigid "either/or" strategies of international PR. They subscribe to the previously introduced "global" communication strategy of the hybrid model in which corporate statements need to be globally uniform, whereas national languages and cultural knowledge of formulations and other national standards, however, are individually adapted in each country (Johanssen \& Steger, 2001, p. 12).

Following this logic, Stöhr (2005, p. 58) uses the concept of "standardized differentiation" to describe the same phenomenon. A similar practice-oriented approach can be found in the latest German language anthology on international business communication (Langen, Sievert, \& Bell, 2007). The latter findings can therefore be positioned in the middle of the continuum between polycentrism and ethnocentrism because they focus on the management of PR from a problem centered approach by taking a closer look at the specific PR activities executed by international organizations.

\subsubsection{Studies on the degree of localization of organizational public relations in host countries}

One of the first comprehensive German-language studies which can be located toward the polycentric side of the continuum (Fig. 1) can be found in the work of Andres (2004). She examines the societal developments and the impact of globalization on international PR of the 250 largest, German-based business enterprises. Within her study, she develops the first comprehensive model to study global PR practices, called the influence model of international PR. The model uses the assumptions and variables of the Excellencein-Public-Relations Theory (Grunig, 1992), which are developed further for the study of corporate PR by aspects of Zerfaß's (2004) theory of corporate communication.

In her model, Andres (2004, p. 195) also refers to corporate structures, corporate cultures and intercultural management aspects of an organization, which were not explicitly taken into account by Grunig (1992). The central findings of her study reveal that only about half of the companies investigated practice international PR at all. When asked about the impact of societal changes on PR, 85\% 
of all organizations indicated that PR has changed through processes of globalization. In particular, communication with foreign media and the integration of national differences were considered to be new aspects of international PR among the companies surveyed (Andres, 2004, p. 318f.). Another central finding is that most companies do not follow a uniform international PR strategy. The surveyed companies allow their subsidiaries to have their own PR to a large extent. However, there are some topics which are seen to be of global significance and consequently need to be handled uniformly at headquarters (Andres, 2004, p. 320). The latter indicates that transnationally operating companies do not pursue a purely ethnocentric communication strategy in PR.

One of the most recent studies of international PR is Klare's (2010) investigation which examines the general conditions of PR in a host country requiring a differentiation approach of local communication activities (compared to home country PR). Klare also bases her considerations on Zerfaß's (2004) understanding of publics and PR, as well as on structuration theory (Giddens, 1984). She describes the question of standardization or differentiation measures of PR as a field of tension between the perspectives of agency and structure of an organization (Klare, 2010, p. 120). The results of her survey of 56 PR professionals working for German companies in China reveals that the degree of localization of PR communication can generally be attributed to the strategic relevance of a host country for the entire company. In addition, Klare outlines PR strategy aspects which are locally directed to the communications market in China. Crucial for the degree of PR polycentrism in China, in particular, is the authoritarian political system, which also controls the media system, as well as cultural and linguistic characteristics. In terms of PR-topics and PR-content, Klare observes an urgent need for local PR and the accentuation of corporate contributions to China (in particular with CSR issues) as well as the sensitive handling of potential scandal topics (Klare, 2010, p. 308f.). In addition, the interpersonal relationships between local PR professionals and journalists seem to be of extreme importance.

However, Klare also identifies areas in which companies hold on to the routines of their home countries, which can thus be seen as "global strategy elements" of the analysis. Such strategies, however, are largely limited to flow charts for press conferences, the compilation of press kits and press clippings to monitor PR success. Even ethical issues of PR in China comply with "German" standards, to a large extent. Klare attributes the latter findings to congruence of such standards in both countries. These include an open, honest communication as well as fair and respectful contact with each other (Klare, 2010, p. 324).

Although the study permits far-reaching insight into the degree of PR-localization in a host country, the results and conclusions of the qualitative research design do not allow a generalization of the findings. Therefore, further investigations in additional countries are needed to supplement and verify Klare's (2010, p. 327) research.

\subsection{International comparative $P R$ research}

The field of comparative international PR research is currently the most heavily researched area of international PR. Another characteristic of international comparative PR research is the strong dominance of English language contributions, which may also add to the large number of studies in this field (Bardhan, 2003; McKie \& Munshi, 2007; Sriramesh, 2004). Consequently, focus of research of international PR in the Anglo-American world differs from the approaches taken by German-speaking scholars. The most important pioneering Anglo-American works, apart from some early discussions in the 1960s, include those of Anderson (1989), Wouters (1991), Botan (1992), Grunig and White (1992), Sharp (1992) and Wilcox et al. (1989). The first English-language anthology of comparative PR research was published by Culbertson and
Chen (1996), which includes seminal theoretical and practical considerations of PR in different countries. A first-time description of historical developments, along with contemporary issues and specific scientific approaches to PR as well as descriptions of PR in 27 European countries can be found in van Ruler and Verčič (2004), however the authors do not compare PR activities between countries. Tilson and Alozie's (2004) anthology examines a broad range of international PR practices and institutions (governments, PR firms and corporations) in emerging and developing nations with a discussion of each country's history, economics, culture and communication principles (Tilson \& Alozie, 2004, p. 2). Similarly, Ławniczak (2005) edited a book about the role PR plays in the transitional economies of Eastern Europe. The most recent comprehensive works of comparative PR in the English language are the books by Sriramesh and Verčič (2009b) and the rather practiceoriented work of Freitag and Stokes (2009).

Also in German-language research, scholars have undertaken efforts to describe and reflect on the professional development of PR in some Eastern European countries (Averbeck \& Wehmeier, 2002). From a practical perspective the International Society of the PR's (IPRA) edited anthology (Black, 1993) presents a number of case studies specifically addressing the implementation of excellent PR internationally. Likewise, Sievert and Porter (2009) offer a corporate approach to the global management of communication in different contexts. Looking at the majority of the aforementioned works from the viewpoint of the German research tradition, the research in this area occurs to be limited to the description of national PR professions compared, in order to gain an understanding of the content and context in which PR is practiced internationally (Andres \& Bentele, 2008, p. 595). In the following discussion, we will analyze the most comprehensive models and theories of international comparative research PR in more detail, i.e. the Cultural Model of PR (Huck, 2004), the Global-Excellence-inPublic-Relations Theory by Grunig, Grunig, Sriramesh, Huang, and Lyra (1995) and Verčič et al. (1996), as well as the Culture-EconomicModel of International PR Practice by Curtin and Gaither (2007).

\subsubsection{Culture-PR model}

A first comprehensive examination of international comparative PR research in Germany was brought forward by Simone Huck (2004). Huck explores the relationship between culture and PR. Focusing on possible interactions between culture on one hand and country-specific PR practices on the other hand, which are located in her Culture-PR Model. Even though Huck's framework focuses on analyzing the national culture of each country, corporate culture and individual culture are also considered. With the help of the Culture-PR Model, Huck examines the top-selling companies in Germany, Austria, Denmark, India and the United States by conducting a survey of 119 public relations executives. The results reveal the impact of a country's national culture on the practice of country-specific PR. In particular, the survey results point to a correlation of individual cultures, i.e. the characteristics of the culture at the individual level, and PR, leading Huck to accounting most relevant to this special connection in her model.

\subsubsection{Excellence-in-Global-Public-Relations-Theory}

The majority of studies in the field of international comparative PR research to date are concerned with the Excellence-in-PublicRelations Theory, initially presented by the U.S. research team headed by James Grunig (Freitag \& Stokes, 2009, p. 34; Sallot, Lyon, Acosta-Alzuru, \& Ogata Jones, 2003, p. 51). Four years after the draft of the excellence factors, attempts were made to make excellence research fertile for the international landscape. Basic contributions in this area are the works of Grunig et al. (1995) and Verčič et al. (1996). International excellence research tries to answer the question of whether the excellence factors are 
internationally valid and which ideas and conceptions of PR exist in different societies (Verčič et al., 1996, p. 31). The main objective is to examine how PR is understood and practiced in different countries. Also, the basic conditions of PR within organizational frameworks and the societal environment are illuminated (Klare, 2010, p. 79). Following the tradition of general excellence research Grunig et al. (1995) comprise the 20 factors of excellence from 1992 into nine universal ("generic") principles of excellent public relations in the transnational. The scholars believe that the general principles can be applied globally by all organizations to practice PR successfully (Verčič et al., 1996, p. 34). In addition, they assume specific differences can be found in different cultures, next to the global principles which make it difficult or impossible to successfully practice uniform PR and which, at least, require an application of specific strategies. These "specific variables" are determined by environmental factors and can therefore be described as variables external to the organization (Verčič et al., 1996, p. 40). ${ }^{3}$

Verčič et al. (1996) locate the nine general principles of excellent global PR within the organization. They refer to internal structures and processes which they assume to be constant across cultures. These include: (1) involvement of PR in strategic management, (2) empowerment of $P R$ in the dominant coalition (management level) or direct reporting relationship to senior management, (3) an integrated $P R$ function, (4) PR as a management function separate from other functions, (5) at least one PR practitioner in managing position, (6) a symmetrical system of internal communication, (8) knowledge potential of the PR practitioner for managerial role and symmetric PR and (9) diversity embodied in all public relations roles (Verčič et al., 1996, pp. 36-40).

The five country-specific excellence factors can be located in the vicinity of the organization as societal determinants of PR. They include (1) the political-economic system, (2) culture, (3) the extent of activism, (4) the level of economic and technological development, and (5) the media system (Verčič et al., 1996, p. 40). Wakefield (1997) identifies an additional, sixth specific variable in the course of an excellence-based Delphi study, i.e. language differences. From the second half of the 1990s on, the findings of the global excellence research were further developed and adapted. In 2000, Wakefield (2000) developed a practical Model of World-Class Public Relations, in which categories of development, and professionalism levels were conceptualized on which organizations can be positioned. The results of the study show that the predominant proportion of the examined companies was, at that time, ill-prepared or at least not adequately prepared to meet the demands of international PR. Only a few organizations had developed awareness for international PR, some even became overwhelmed with the challenges of international PR. In addition, European companies performed better than their U.S. counterparts (Wakefield, 2000, p. 69f).

According to Wakefield (2008, pp. 148, 152), the biggest challenges of the Excellence-in-Global-PR-Theory can be found in the Internet, since activist groups around the world can network online, raising the question of whether a repositioning of activism among the generic variables of the theory is needed. In addition, major societal upheavals in many countries around the globe highlight the need for the continuous advancement of the theory since its initial conception.

Based on the Global Excellence factors, other researchers have conducted numerous national studies to test the generic and/or specific principles for their applicability worldwide (Chen, 2005; Hung, 2002; Lim, Goh, \& Sriramesh, 2005; Molleda \& Ferguson, 2004; O'Neil, 2003; Rhee, 2002; Sallot et al., 2003; Sriramesh, Kim, \& Takasaki, 1999; van Dyke, 2005). Some studies focus exclusively

\footnotetext{
${ }^{3}$ This approach has been taken from Brinkerhoff and Ingle's (1989) theory of structured flexibility.
}

on societal aspects of the Global-Excellence-Theory, such as the political-economic system of a country (Dolea, 2012; Kirat, 2005; Molleda \& Suárez, 2005) culture (Huang, 2000; Taylor, 2000; Wu, Taylor, \& Chen, 2001) and activism (Guiniven, 2002). There is also a number of studies investigating the level of $P R$ professionalism (one of the original excellence factors) on the national level (de Bussy \& Wolf, 2009; Gupta, 2007; Kirat, 2006; Niemann-Struweg \& Meintjes, 2008).

In German-language research, Voss (2007) examined the question of how Grunig's excellence factors can be applied to the PR practices of NGOs (environmental organizations). Hence, she conducts written surveys among 58 senior PR-managers to compare the PR practices of NGOs in Germany and the United States. The results of the study show that the excellence factors can largely be applied to NGOs as another type of organization next to profitoriented companies as well. However, the highly media-oriented PR of NGOs primarily uses one-sided communication techniques (Voss, 2007, p. 133).

Sriramesh and Verčič (2003) condensed the five specific global excellence factors into three factors: (1) infrastructure, (2) media system and (3) culture. On the basis of these factors, they continue to describe the PR practices in 17 countries in a portrait style. By doing so, they aim to develop a comprehensive and practical understanding of the environmental variables in different countries around the world.

With the development of their theory Grunig et al. suggest a normative and general research model to explain success or failure of PR in different countries. For this reason, the researchers position their theory between cultural relativism and ethnocentrism (Verčič et al., 1996, p. 33). Even though their approach is widely acknowledged, especially in the Anglo-American world, we can identify a number of scientific publications which criticize the Excellence-in-Global-PR Theory as well. Some researchers point out that traditional excellence research is based on a fragile foundation of empirical data (Pang, Jin, \& Cameron, 2010) and that the mere internationalization of such research does not alter the theory's weak explanatory power (Bardhan \& Weaver, 2011, p. 1). Klare (2010, p. 80 also Banks, 2000, p. 5; Bardhan \& Weaver, 2011 , p. 5f) notes that Grunig follows a simplified cultural understanding which does not adequately account for the complexity of such a social construct. In addition, the aforementioned influence factors on PR practices are said to be plausible, but not derived from theory, and partly even contradictory to social theory (Klare, 2010, p. 17). Other researchers criticize the Excellence-in-GlobalPR-Theory's strong normative character leaving too little room for cultural differences beyond the Western world which still need to be considered in international communication (Bardhan, 2003; Holtzhausen, Petersen, \& Tindall, 2003). Kent and Taylor (2007) point out that the theory's general variables offer good opportunities to describe the general conditions of international PR. However, focusing on the "fulfilment" of these categories does not disclose information about the successful implementation of PR in different countries. Ultimately, the limits of international comparative PR research lie in their limited cognitive interest. Largely, the research focuses on case studies (Moss \& DeSanto, 2002) and comparisons of PR practices in different countries (Sriramesh \& Verčič, 2003), in which PR practices are investigated to unfold certain aspects (Verčič et al., 1996) required to practice excellent PR (Andres, 2004, p. 189).

Next to systematic examinations of the excellence factors in the international sphere, which are largely descriptive in nature, we can observe a (parallel) trend toward descriptions of PR in different countries, which often refer (implicitly) to global excellence factors, but do not explicitly refer to them, or pursue their own national PR model descriptions. Wu (2005, p. 23f), for example, mentions many authors in Asia who put forth country descriptions of PR. Other research describes PR in Latin America, but these works are 
largely written in Spanish and are therefore not well accessible for international scholars (Sriramesh, 2003, p. xxv). Generally speaking, most studies which do not relate to categories of excellence operationalize their core categories in many other diverse ways making it impossible to speak of them as "comparable research" (Klare, 2010, p. 16). For example, Molleda and Moreno (2008) investigate the influence of socio-economic and political context factors on PR practices in Colombia, Mexico and Venezuela using semi-structured interviews with PR managers. However, just like Sriramesh and Verčič (2003), their findings are not directly compared to each other, but rather remain descriptions on their own.

\subsubsection{Recent developments in international comparative $P R$ research: the Culture-Economic-Model of International Public Relations practice}

Over the years, and not at last due to the criticism on excellence research, a tendency to develop alternative approaches to international comparative PR research has evolved. In Bardhan and Weaver's (2011) anthology, several authors point at the strong cultural and global interdependences of international PR, which can be better described and understood through interpretive, culture critical, postmodern and social-scientific approaches, than by Grunig's "antiquated views" (Bardhan \& Weaver, 2011, p. ix-1).

Following this notion, Curtin and Gaither (2007) develop a Culture-Economic-Model of International Public Relations Practice from a cultural studies perspective, which is designed to provide a new and culturally centered approach to studying PR. Their model emphasizes the cultural conditioning of the communicative relationships on which PR is based. Conceptually, the model resembles the "Circuit of Culture Process Model" (Curtin \& Gaither, 2007, p. 38 ). In both models the interaction of five elements - called "five moments" - describes cultural differences between regions, which in turn, can be taken into account in PR communication. These items are regulation, representation, identity, production and consumption (Curtin \& Gaither, 2007, pp. 38-48). Through the analysis of the five cultural factors' interaction, PR practitioners should learn to act as cultural mediators who value and access the communication needs of different cultural groups (Curtin \& Gaither, 2007, p. 210f.). The aforementioned researchers emphasize that their model does not center on Western PR practices, as it is not designed to fill in "fixed" categories, but rather supports a process-related view on PR. The model has already been applied in pioneer studies to investigate the influence of national cultural value orientations on PR practice in the same country (Al-Kandari \& Gaither, 2011), meaning it conceptually provokes country comparisons.

\subsection{International $P R$ of nations}

There are only a few studies which have systematically and empirically investigated nation PR. One worth mentioning is Bogart's (1976) research into the activities of the US-information agency (USIA) as well as Hertz's (1982) and Karl's (1982) investigation into the influence of media reporting on a country's foreign politics. Manheim and Albritton (1984) are interested in the effects of positively connoted PR press releases about different nations on subsequent media reporting about these countries. They reveal that a country's national image cannot be positively influenced through agency re-ports in short time and that media reporting about almost all countries tended to decrease. In the field of public diplomacy research, Signitzer and Coombs (1992) come to the conclusion that diplomats act as national actors in the public, and therefore have a special influence on a county's image abroad.

One of the few German-language studies in the field is Hans Süßmuth's (1994) study on the image of Germany in Denmark, England, France and the Netherlands. Although Süßmuth's study can be located within the area of political communication since he examines the influence of Germany's politics on its nation image, it nevertheless posits an insightful measurement of mediated national images. Also, major sports events have been the object of investigation in nation PR research in the past. In such studies, the primary focus is on examining the (place of location) communication of nations in regard to world championships and Olympic Games (Vitiello, 2008).

Among contracted research, which largely focuses on practitioners needs and interests, we can find an increasing amount of studies concerned with the effectiveness of nation PR. For example, the study by Pasquier et al. (2009) on the image of Switzerland abroad or the work of Karten (2008), who examines the German foreign affairs office's public image campaign. In such studies, a country's image is influenced by various factors such as political developments, the beauty of the landscape, or even famous people who stand for a country (Pasquier et al., 2009). Some countries, e.g. Switzerland (Ingenhoff et al., 2013), even take efforts to institutionally manage their nation's images.

The majority of investigations in the communication practices of countries, or nation image research, can be found in the field of business administration and marketing. The main topic of such research is the positioning of countries internationally with the help of branding strategies (Anholt, 2007, 2009; Dinnie, 2007; Gilmore, 2001; Olins, 2002; Passow, Fehlmann, \& Grahwohl, 2005; Szondi, 2009, p. 134ff) in order to attract economic investment, market national products (Nagashima, 1970) or promote tourism (Lee \& Yoon, 2010). A first approach toward analyzing the role of tourism PR in the stress field of economics and culture is suggested by Hoffmann (2013).

\section{Culture as the most important determinant of international PR}

From the analysis of the state of research it becomes evident that researchers unanimously agree on the cultural determinism of PR in the international arena (e.g. Andres, 2004, p. 20; Banks, 2000; Bardhan \& Weaver, 2011; Curtin \& Gaither, 2007, p. 13; Huck, 2004, p. 18f; Klare, 2010, p. 27ff; Sriramesh, Grunig, \& Dozier, 1996; Verčič et al., 1996; Wakefield, 2008). Hence, Huck (2004, p. 18) and Bardhan and Weaver (2011, p. 8) describe culture as the central aspect of international PR. But what do we mean by "culture" and which difficulties arise when we want to measure this construct?

In social sciences, no universally accepted definition of culture has been developed so far (Koopman, Den Hartog, \& Konrad, 1999, p. 506). Many researchers, however, refer to Tyler (1871) who describes culture as consisting of such elements people share with each other and which they have acquired due to their affiliation to a group. This also includes all other skills and habits people have as members of a society (Tyler, 1871, p. 1). ${ }^{4}$ Hofstede and Hofstede (2009, p. 4) share these assumptions when they define culture as a collective phenomenon, as unwritten rules and collective programming of the mind which distinguishes one group from another. Culture sets the context for the interpretation of social events, defines motives, values, beliefs and identities which are shared by their respective group members and passed on through generations (House \& Javidan, 2004, p. 15). Thus, culture is primarily acquired by individuals and derived from one's immediate social environment. In this process, members of a society continually update and modify their respective culture.

\footnotetext{
${ }^{4}$ Kroeber and Kluckhohn (1952) compiled and analyzed more than 150 definitions of culture which had been put forward in literature over a period of more than 150 years. Backgrounds critically start reflecting on their own actions by interacting with other cultures and consequently adapt or change their own views and cultural values in favor of their counterparts' characteristics (Casimir, 1993, p. 422).
} 
When looking at the cultural dimensions of PR, it is worth noting the fact that research encounters difficulties in grasping cultural spaces (and thus PR) in an international context as well as difficulties in making such spaces empirically measurable and definable. Under the heading of "cultural globalization" one arrives at the question of whether we encounter a trend toward converging global societies resulting in a possible homogenization, or rather a counter trend toward a heterogenisation of culture. Likewise, signs for both tendencies can be detected (Robertson, 1993; Stevenson, 2000). Sometimes researchers also discuss the emergence of a third culture effect, which describes the possibility of multiple interactions of different cultures which possibly create a mixed culture. This mixed culture is no longer strictly attributable to one primary culture, e.g. when individuals from different cultural backgrounds critically start reflecting on their own actions by interacting with other cultures and consequently adapt or change their own views and cultural values in favour of their counterparts' characteristics (Casimir, 1993: 422).

\subsection{Hofstede's cultural dimensions}

From the perspective of cultural relativism Hofstede (1980) designed a study in which he surveyed managers of one company in 40 countries to draw conclusions on their respective national cultures. The aim of the study was to analyze differences in "citizenship" between areas of culture worldwide. In this context Hofstede developed country profiles which serve as a basis to compare different national cultures worldwide.

The basic typologies of cultural dimensions defined by Hofstede $\underline{(1980)}$ dominate cross-cultural research. His four basic dimensions are designed as bipolar scales and include (1) power distance, (2) collectivism vs. individualism, (3) femininity vs. masculinity and (4) uncertainty avoidance. These dimensions were complemented a few years later with a fifth dimension, i.e. long-term vs. shortterm orientation (Hofstede \& Hofstede, 2009, pp. 30-34). The cultural dimensions have influenced research worldwide greatly, and have also become generally accepted dimensions of international PR research to investigate "PR cultures" in different countries (e.g. Cooper-Chen \& Tanaka, 2008; Huck, 2004; Ihator, 2000; Kang \& Mastin, 2008; Kim \& Kim, 2010; Molleda \& Ferguson, 2004; Rhee, 2002; Sriramesh, 1996; Sriramesh \& Verčič, 2001; Vasquez \& Taylor, 2000; Wu \& Baah-Boakye, 2007; Wu et al., 2001).

Despite their popularity some PR researchers doubt the applicability of Hofstede's cultural dimensions in an age of globalization (Bardhan \& Weaver, 2011; Courtright, Wolfe, \& Baldwin, 2011). They think that the social conditions in the 21st century, the Internet, the growing mobility of the world's population and the development of international global economies do not embrace Hofstede's dimensions any longer, given the fact that his data was gathered in end of the 1960s and the beginning of the 1970s. Thus, his critiques express a need to conceptualize cultural dimensions in more complex terms (Bardhan \& Weaver, 2011, p. 2). Above all, critics emphasize a "deterritorialisation" of national cultures, which has led to a present situation of global cultural fragmentation. Hofstede's dimensions are judged to be too static and too closely bound to national borders (Courtright et al., 2011) and consequently frame nation-states as "containers of culture" (Bardhan \& Weaver, 2011, p. 2). Other criticism is expressed toward the validity and reliability of Hofstede's method. Furthermore, the introduction of a fifth dimension, which is the result of an empirical examination of the four cultural dimensions in China in 1987 is criticized, raising questions of whether the dimensions represent exhaustive criteria for the study of culture; or whether other dimensions are plausible as well, but simply have not been formulated yet (Courtright et al., 2011, p. 113).
In light of such criticisms, it is surprising that Hofstede's cultural dimensions are still widely applied in research. One reason could be that they contain data for almost all countries of the world which can simply be used as criteria for cultural comparisons (Klare, 2010, p. 332).

\subsection{The GLOBE-study}

The GLOBE-study (Global Leadership and Organizational Behavior Effectiveness Research Program) is based on a survey of over 17,300 managers from 951 different organizations over a period of 10 years and seeks to investigate different elements of culture in 59 countries. More specifically, the study aims to gather information about the prevailing moral concepts in organizational and social environments (House et al., 2004, p. xv; Gupta \& Hanges, 2004, p. 190f). The aim of this study was to determine the relationships between national culture, organizational culture and organizational leadership and to make their relationships measurable for research. By doing so, the researchers aimed to establish a reliable theory of culturally based differences between cultural norms and organizational leadership in an era of globalization.

The cultural dimensions developed by House et al. build in part on Hofstede's model, yet they were extended conceptually. House et al. adopt the dimensions of "uncertainty avoidance" and "power distance." Hofstede's collectivism/individualism and femininity/masculinity dimensions are expanded with two additional dimensions: "institutional collectivism" refers to the degree to which the practices of organizational and social institutions support collective action and the allocation of resources, as well as "in-group collectivism" which describes the degree to which individuals act loyally and are proud of their affiliation to organizations/families. With regard to gender issues, House et al. distinguish between "gender egalitarism" which is the degree to which a collective minimizes inequality between sexes, and "assertiveness" as the degree to which members of a society act assertively, aggressively, and confrontationally with one another. In addition, House et al. develop three other dimensions according to Kluckhohn and Strodtbeck (1961) and McClelland (1985): These are the "future orientation," "achievement orientation" and "humane orientation" which describe the degree to which a society rewards individuals for being fair, generous, caring and for acting altruistically toward each other.

A major feature of the GLOBE study lies in the fact that cultures are not as discriminated by national borders (as Hofstede), but are seen as societal areas which can be divided into so-called cluster regions on the basis of certain characteristics inherent in each societal culture. For example, Germany, Austria, Germanspeaking Switzerland and the Netherlands build the Germanic cluster; France, Israel, Italy, Portugal, Spain and French-speaking Switzerland make up the Latin European cluster (House et al., 2004, p. 32ff). Although the study by House et al. accounts for the processes of (cultural) globalization better than Hofstede's study, the validity of the findings remains limited to the enquiry of members of the companies' middle management. Furthermore, the GLOBEstudy's cluster configuration does not take into account the national subcultures of all the countries investigated. For example, the Italian and Rhaeto-Romanic-speaking part of Switzerland, as well as subcultures in China, Malaysia, India and the United States are excluded from the analysis.

\section{Conclusion and future prospects}

From the preceding literature review it should have become clear that culture is seen to be the main determinant of international PR (Bardhan \& Weaver, 2011; Huck, 2004). In this respect, particularly research on internationally oriented PR 
practices of organizations, as well as international comparative PR are concerned with the general conditions of PR in the multinational. The discussions about standardization and localization debates of global PR measures show that research has come to recognize a minimum level of polycentrism in PR (Andres, 2004; Verčič et al., 1996), yet has been hesitant to yield investigations on the local, specialized level (Klare, 2010).

In general, we face a deficient state of knowledge on international PR, especially in German-language research. ${ }^{5}$ So far the findings produced within the Anglo-American comparative research tradition stand out, as they're primarily concerned with Grunig's (1992; Verčič et al., 1996; Grunig et al., 1995) excellence factors, and criticized to be insufficiently theory oriented. In contrast, German-speaking research is largely characterized by pursuing an organizational sociology, systems theoretical (Ronneberger \& Rühl, 1992) or structuration theoretical (Röttger, 2005; Zerfaß, 2004) perspective which has been poorly received in Anglo-American research as of yet. One reason for this deficiency certainly lies in the fact that many of such works are written exclusively in German (Sandhu \& Huck-Sandhu, 2013).

Also existing literature on international nation PR, or public diplomacy, is rudimentary in numbers both in English and in German scholarship, and hardly follows systematic-empirical approaches (Kunczik, 2003, Szondi, 2009, p. 145). Possible reasons for this condition are brought forward by Bentele (2001), who highlights the difficulties in influencing the image of a country through PR in a positive way. Thus, social issues within a nation occur relatively autonomous from their environment, i.e. other countries.

Research so far has had difficulties in grasping cultural areas internationally. The discussed cultural dimensions provide concepts for the differentiation and investigation of culture. However, it appears that through the developments of globalization national borders can no longer be seen as static lines of cultural separation. The latter are becoming increasingly blurred with increasing mobility of the world's population, questioning the applicability of Hofstede's considerations in parts. To adequately reflect societal geographies today, the naturally given multi-culturalism existing in many different countries worldwide needs to be taken into account more explicitly than before. This also finds support with Banks (2000, p. 20) who sees the central challenges of multicultural PR in the need for extensive involvement of various cultural subgroups in a given society. The findings of the GLOBE-study (House et al., 2004) provide useful a starting point for this purpose.

The study of international PR under the paradigm of different cultures is always concerned with the problem that the researcher's own cultural "spectacles" shape his/her look at the research object. Still, this limitation can usually not be perceived consciously, which also affects the applied research methodology. Hall (1966, p. 177) already addressed the problem of one's own cultural fixedness in the study of other cultures. At the same time, research in the field of international PR is almost inevitably dependent on dimensional categories from existing, extensive cultural studies such as the works of Hofstede and House et al. to investigate countries and cultural areas, since it is hardly possible to perform additional inquiries of each culture being studied facing the already high complexity of international PR.

Next to culture, international PR in the globalized world faces other challenges, which are largely left unexplored. For example, we can address the important role the Internet plays in the implementation of PR practices within online communication (Johanssen \& Steger, 2001; Passow et al., 2005). Especially the use,

\footnotetext{
${ }^{5}$ Even the current edition of the German-language Handbook of Public Relations (Bentele, Fröhlich, \& Szyszka, 2008) does not include a section on international public relations.
}

potential and risks of online communication, but also social media, to achieve the goals of international PR (Bähni et al., 2013; Schmid et al., 2013) are of interest. Wakefield (2008) raises the question of whether activism becomes a universal, generic variable of PR because most activists' actions against international organizations are communicated globally on the web. At the same time, occurring network effects through social media need to be explored which will increasingly become relevant for international PR in this context. Such developments also impact issues management. Issues from now on need to be detected and monitored internationally (online) and processed in many cultural areas simultaneously (Ingenhoff \& Röttger, 2013). The same applies to the crisis PR (Schwarz, 2013). The new research questions to be asked in the areas therefore are: Which challenges and processing logics does globalization pose to the management of issues and crisis PR in international organizations, also in regard to their (new) stakeholders?

The Internet also raises the question of whether polycentric PR is possible in different countries at all, if the Internet addresses a "world public" as recipient of PR. Thus, the conditions of online and social media PR contrast localized PR, which can lead to discrepancies in the communicated PR messages and raises questions about the possible harmonization of international communication strategies of online and offline PR in general.

Next to the inclusion of PR job-descriptions in different countries (e.g. van Ruler \& Verčič, 2004) into PR education and training, it is particularly important to integrate cultural characteristics existent in different social areas in future PR training and to clarify potential differences and externalities from different training practices in the international environment.

An equally challenging field is the communication of social responsibility, also known as Corporate Social Responsibility (CSR), which must be relocated with regard to international PR. The questions of standardization or differentiation strategies of international communication apply here as well: Which factors determine the development of CSR programs on a national or global basis? (Huck-Sandhu, 2011, p. 224). The first attempt toward a theoretical-methodological framework of international CSR can be found in Huck (2011) and Jarolimek (2013).

In this contribution, we have mapped the field of international PR research and outlined links for future research. Finally, we will note that international PR ultimately represents a research area which is still in its infancy - but its effects offer far-reaching and exciting implications for many other areas of PR which need to be explored in more detail in the future.

\section{References}

Al-Kandari, A., \& Gaither, T. K. (2011). Arabs, the west and public relations: A critical/cultural study of Arab cultural values. Public Relations Review, 37, 266-273. Anderson, G. (1989). A global look at public relations. In B. Cantor (Ed.), Experts in action. Inside public relations (pp. 412-422). White Plains, NY: Longman.

Andres, S. (2004). Internationale Unternehmenskommunikation im Globalisierungsprozess. Eine Stu-die zum Einfluss der Globalisierung auf die 250 größten in Deutschland ansässigen Unternehmen. Wiesbaden: VS Verlag.

Andres, S., \& Bentele, G. (2008). Internationale public relations. In G. Bentele, R Fröhlich, \& P. Szyszka (Eds.), Handbuch der Public Relations. Wissenschaftliche Grundlagen und berufliches Handeln. Mit Lexikon (p. 595). Wiesbaden: Verlag für Sozialwissenschaften.

Anholt, S. (2007). Competitive identity: The new brand management for nations, cities and regions. Basingstoke, Hampshire: Palgrave Macmillan.

Anholt, S. (2009). Places: Identity, image and reputation. Basingstoke, Hampshire: Palgrave Macmillan.

Averbeck, S., \& Wehmeier, S. (2002). In R. Steinmetz (Ed.), Kommunikationswissenschaft und Public Relations in Osteuropa: Arbeitsberichte. Leipzig: Leipziger Universitätsverlag.

Bähni, A., Barth, E., \& Ingenhoff, D. (2013). Der Einfluss von Kultur in der OnlineKommunikation von NGOs: Eine international vergleichende Studie. In D. Ingenhoff (Ed.), Internationale PR-Forschung (pp. 111-136). Konstanz: UVK Verlag.

Banks, S. P. (2000). . Multicultural public relations. A social-interpretive approach (Vol. 2) Ames: Iowa State Press. 
Barboza, D., \& Stone, B. (2010). China, Where U.S.: Internet Companies Often Fail. Retrieved from http://www.nytimes.com/2010/01/16/technology/ 16 failure.html?pagewanted=all (04.03.12)

Bardhan, N. (2003). Rupturing public relations metanarratives: The example of India. Journal of Public Relations Research, 15, 199-223.

Bardhan, N., \& Weaver, C. K. (2011). Introduction. In N. Bardhan, \& C. K. Weaver (Eds.), Public relations in global cultural contexts. Multi-paradigmatic perspectives (pp. 1-28). New York/London: Routledge.

Barovick, R. (1982). Activism on a global scale: The infant-formula controversy marked the first time activist groups teamed up world-wide. Public Relations Journal, 38(6), 29-31.

Bentele, G.(2001, 25 Juli). Nationenimages als Teil derinternationalen Kommunikation. Gliederungspunkt: Handbuch PR.

Bentele, G., Fröhlich, R., \& Szyszka, P. (2008). Handbuch der Public Relations. Wissenschaftliche Grundlagen und berufliches Handeln. Mit Lexikon. Wiesbaden: Verlag für, Sozialwissenschaften.

Black, S. (1993). International public relations. London: Kogan Page.

Bogart, L. (1976). Premises for propaganda: The U.S. information agency's operating assumptions in the Cold War. New York: Free Press.

Botan, C. (1992). International public relations: Critique and reformulation. Public Relations Review, 18(2), 149-159.

Brinkerhoff, D. W., \& Ingle, M. D. (1989). Integrating blueprint and process: A structured flexibility approach to development management. Public Administration and Development, 9, 487-503.

Casimir, F. (1993). Third-culture building: A paradigm shift for international and intercultural communication. Communication Yearbook, 16, 407-428.

Chen, Y. R. (2005). Excellent public affairs in an era of marketization: Issues management, business lobbying, and the management of government relations in China (Unpublished dissertation). University of Maryland, College Park.

Cooper-Chen, A., \& Tanaka, M. (2008). Public relations in Japan: The cultural roots of Kouhou. Journal of Public Relations Research, 20(1), 94-114.

Courtright, I., Wolfe, R., \& Baldwin, I. (2011). Intercultural typologies and public relations research: A critique of Hofstede's dimensions. In N. Bardhan, \& C. K. Weaver (Eds.), Public relations in global cultural contexts. Multi-paradigmatic perspectives (pp. 108-139). New York/London: Routledge.

Culbertson, H. M. (1996). Introduction. In H. M. Culbertson, \& N. Chen (Eds.), International public relations. A comparative analysis (pp. 1-13). Mahwah: Lawrence Erlbaum.

Culbertson, H. M., \& Chen, N. (1996). International public relations: A comparative analysis. Mahwah, NJ: Lawrence Erlbaum.

Curtin, P. A., \& Gaither, T. K. (2007). International public relations. Negotiating culture, identity, and power. Thousand Oaks, CA: Sage.

de Bussy, N. M., \& Wolf, K. (2009). The state of Australian public relations: Professionalisation and paradox. Public Relations Review, 35, 376-381.

Delaney, R. (1968). Introduction. In A. S. Hoffmann (Ed.), International communication and the new diplomacy. Bloomington: Indiana University Press.

Dinnie, K. (2007). Nation branding: Concepts, issues, practice. Amsterdam: Butterworth-Heinemann.

Dolea, A. (2012). Institutionalizing government public relations in Romania after 1989. Public Relations Review, 38(3), 354-366.

Dornis, P. (1971). Public Relations in der internationalen Unternehmung. Grundlagen, Entschei-dungsstruktur und Strategien. Meisenheim am Glan: Hain.

Freitag, A. R., \& Stokes, A. Q. (Eds.). (2009). Global public relations. Spanning borders, spanning cultures. Abingdon/New York, NY: Routledge.

Giddens, A. (1984). The constitution of society. Outline of the theory of structuration. Cambridge: Polity Press.

Gilmore, F. (2001). A country - can it be repositioned? Spain - the success story of country branding. Brand Management, 9(4-5), 281-293.

Grunig, J. E. (1992). Excellence in public relations and communication management. New Jersey: Lawrence Erlbaum Associates.

Grunig, J. E. (2006). Furnishing the edifice: Ongoing research on public relations as a strategic management function. Journal of Public Relations Research, 18(2), 151-176.

Grunig, J. E., \& White, J. (1992). The effect of worldviews on public relations. In J. E. Grunig (Ed.), Excellence in public relations and communication management ( $\mathrm{pp}$. 31-64). Hillsdale, NJ: Lawrence Erlbaum.

Grunig, J. E., Grunig, L. A., Sriramesh, K., Huang, Y.-H., \& Lyra, A. (1995). Models of public relations in an international setting. Journal of Public Relations Research, $7(3), 163-186$

Guiniven, J. E. (2002). Dealing with activism in Canada: An ideal cultural fit for the two-way symmetrical public relations model. Public Relations Review, 28, 393-402.

Gupta, S. (2007). Professionalism in Indian public relations and corporate communications: An empirical analysis. Public Relations Review, 33, 306-312.

Gupta, V., \& Hanges, P. J. (2004). Regional and climate clustering of societal cultures. In R. J. House, P. J. Hanges, M. Javidan, P. W. Dorfman, \& V. Gupta (Eds.), The GLOBE Study of 62 Societies (Vol. 1) Culture, leadership and organizations (pp. 178-218). Thousand Oaks, CA: Sage.

Hall, E. T. (1959). The silent language. New York: Anchor.

Hall, E. T. (1966). Hidden dimension. New York: Anchor.

Hall, E. T. (1976). Beyond culture. New York: Anchor.

Heller, F. (1988). Cost benefits of multinational research on organizations. International Studies of Management and Organizations, 18, 5-18.

Henneke, K. (1998). Internationale PR. Systematisierung und konstruktivistische Perspektivierung eines Phänomens der Informationsgesellschaft (Dissertation). University of Münster. Available on micro-fiche an der FU Berlin.
Hertz, J. H. (1982). Political realism revisited. International Studies Quarterly, 25. Hoffmann, J. (2013). Die kommunikative Vernichtung kultureller Kontingenz. Eine Theorie der Tourismus-PR. In D. Ingenhoff (Ed.), Internationale PR-Forschung (pp. 207-227). Konstanz: UVK Verlag.

Hofstede, G. (1980). Culture's consequences: International differences in work-related values. Newbury Park, CA: Sage.

Hofstede, G., \& Hofstede, G. J.(2009). Lokales Denken, globales Handeln: interkulturelle Zusammenarbeit und globales Management. München: dtv.

Holtzhausen, D. R., Petersen, B. K., \& Tindall, N. T. J. (2003). Exploding the myth of the symmetrical/asymmetrical dichotomy: Public relations models in the New South Africa. Journal of Public Relations Research, 15(4), 305-341.

House, R. J., \& Javidan, M. (2004). Overview of GLOBE. In R. J. House, P. J. Hanges, M. Javidan, P. W. Dorfman, \& V. Gupta (Eds.), The GLOBE Study of 62 Societies (Vol. 1) Culture, leadership and organizations (pp. 9-28). Thousand Oaks, CA: Sage.

House, R. J., Hanges, P. J., Javidan, M., Dorfman, P. W., \& Gupta, V. (2004). Culture leadership, and organizations: The GLOBE study of 62 societies. Thousand Oaks, CA: Sage Publications.

Howard, C. M. (1997). Going global: How to expand your horizons while avoiding the "ugly American" syndrome. Public Relations Quarterly, 4, 21-27.

Huang, Y.-H. (2000). The personal influence model and Gao Guanxi in Taiwan Chinese public relations. Public Relations Review, 26(2), 219-236.

Huck, S. (2004). Public relations ohne Grenzen? Eine explorative Analyse der Beziehung zwischen Kultur und Öffentlichkeitsarbeit von Unternehmen. Wiesbaden: VS Verlag

Huck, S. (2007). Internationale Unternehmenskommunikation. In A. Zerfaß, \& M Piwinger (Hrsg.): Handbuch Unternehmenskommunikation (pp. 891-904). Wiesbaden: Gabler.

Huck-Sandhu, S. (2011). Corporate social responsibility und international public relations. In J. Raupp, S. Jarolimek, \& F. Schulz (Eds.), Handbuch CSR. Kommunikationswissenschaftliche Grundlagen, disziplinäre Zugänge und methodische Herausforderungen. Mit Glossar (p. 205228). Wiesbaden: VS Verlag.

Hung, C. J. F. (2002). The interplays of relationship types, relationship cultivation, and relationship outcomes: How multinational and Taiwanese companies practice public relations and organization-public relationship management in China (Unpublished dissertation). University of Maryland, College Park.

Ihator, A. (2000). Understanding the cultural patterns of the world - An imperative in implementing strategic international PR programs. Public Relations Quarterly. 45(5), 38-44.

Ingenhoff, D., \& Röttger, U. (2013). Neue Rahmenbedingungen und Herausforderungen des Issues Management. In Hoffjann, O., Huck-Sandhu, S. (Hrsg.) UnVergessene Diskurse: 20 Jahre PR- und Organisationskommunikationsforschung. Wiesbaden: Springer VS Verlag, in press.

Ingenhoff, D., Lais, C., \& Zosso, J. (2013) Länderimages und die Rolle der Kultur. In Ingenhoff, D. (Hrsg.). Internationale PR-Forschung (pp. 183-206). Konstanz: UVK Verlag.

Jarolimek, S. (2013). CSR-Kommunikation im interkulturellen Vergleich. Von der unternehmerischen Selbstbeschreibung zum (welt) gesellschaftlichen Phänomen CSR. In Ingenhoff, D. (Hrsg.). Internationale PR-Forschung (pp. 87-110). Konstanz: UVK Verlag.

Johanssen, K.-P., \& Steger, U. (2001). Lokal oder global? Strategien und Konzepte von Kommunikati-ons-Profis für internationale Märkte. Frankfurt am Main: F.A.Z.Institut.

Kang, D. S., \& Mastin, T. (2008). How cultural difference affects international tourism public relations websites: A comparative analysis using Hofstede's cultura dimensions. Public Relations Review, 34, 54-56.

Kanso, A. (1992). International advertising strategies: Global commitment to loca vision. Journal of Advertising Research, 32(1), 10-14.

Karl, P. M. (1982). Media diplomacy. In G. Benjamin (Ed.), The communication revolution in politics. Proceedings of the academy of political science (Vol. 34).

Karten, B. I. (2008). Staatliche Imagearbeit: Die Public Diplomacy des Auswärtigen Amtes. In T. Jäger, \& H. Viehrig (Eds.), Die amerikanische Regierung gegen die Weltöffentlichkeit? (pp. 163-190). Wiesbaden: VS Verlag.

Kent, M. L., \& Taylor, M. (2007). Beyond excellence: Extending the generic approach to international public relations. The case of Bosnia. Public Relations Review, 33 10-20.

Kim, Y., \& Kim, S.-Y.(2010). The influence of cultural values on perceptions of corporate social responsibility: Application of Hofstede's dimensions to Korean public relations practitioners. Journal of Business Ethics, 91, 485-500.

Kinzer, H. J., \& Bohn, E. (1985). Public relations challenges of multinational corporations. Paper presented at the international communication association conference, Honolulu.

Kirat, M. (2005). Public relations practice in the Arab World: A critical assessment Public Relations Review, 31, 323-332.

Kirat, M. (2006). Public relations in the United Arab Emirates: The emergence of a profession. Public Relations Review, 32, 254-260.

Klare, J. (2010). Kommunikationsmanagement deutscher Unternehmen in China. Wiesbaden: VS Verlag.

Kleebinder, H.-P. (1995). Internationale Public Relations. Analyse öffentlicher Mein ungsbildung in Europa zum Thema Mobilität. Wiesbaden: Gabler.

Kluckhohn, F. R., \& Strodtbeck, F. L. (1961). Variations in value orientations. New York: Harper Collins.

Koopman, P. L., Den Hartog, D. N., Konrad, E., et al. (1999). National culture and leadership profiles in Europe: Some results from the GLOBE study. European Journal of Work and Organizational Psychology, 8(4), 503-520.

Kroeber, A., \& Kluckhohn, C. (1952). Culture: A critical review of concepts and definitions. Cambridge, MA: Harvard University Press. 
Kruckeberg, D. (1996). A global perspective on public relations ethics: The Middle East. Public Relations Review, 22, 181-189.

Kunczik, M. (1992). Internationale Public Relations als Forschungsfeld. In H. Avenarius, \& W. Arm-brecht (Eds.), Ist Public Relations eine Wissenschaft? Eine Einführung (pp. 335-370). Opladen: Westdeutscher Verlag.

Kunczik, M. (1997). Images of nations and international public relations. Mahwah, NJ: Lawrence Erlbaum.

Kunczik, M. (2003). Transnational public relations by foreign governments. In K Sriramesh, \& D. Verčič (Eds.), The global public relations handbook. Theory, research and practice (Vol. 1) (pp. 399-424). Mahwah, NJ: Lawrence Erlbaum.

Langen, C. Sievert, H., \& Bell, D. (2007). Strategisch kommunizieren und führen. Profil und Qualifizierung für eine transparente und internationale Unternehmenskommunikation (Vol. 2) Verlag Bertelsmann Stiftung.

Ławniczak, R. (Ed.). (2005). Introducing market economy institutions and instruments: The role of public relations in transition economies. Poznań: Piar

Lee, S., \& Yoon, Y. (2010). Return on investment (ROI) of international public relations: A country-level analysis. Public Relations Review, 36, 15-20.

Lim, S., Goh, I. \& Sriramesh, K. (2005). Applicability of the generic principles of excellent public relations in a different cultural context: The case study of Singapore. Journal of Public Relations Research, 17, 315-340.

Lützler, T. (2007). Internationalisierung in Global Communications - eine Einführung. In C. Langen, H. Sievert, \& D. Bell (Eds.), Strategisch kommunizieren und führen. Profil und Qualifizierung für eine transparente und internationale Unternehmenskommunikation (Vol. 2). Gütersloh: Verlag Bertelsmann Stiftung.

Manheim, J. B., \& Albritton, R. B. (1984). Changing national images: Internationa public relations and media agenda setting. American Political Science Review. 78(4), 641-657.

McClelland, D. C. (1985). Human motivation. Glenview, IL: Scott, Foresman.

McKie, D., \& Munshi, D. (2007). Reconfiguring public relations: Ecology, equity, and enterprise. New York: Routledge.

Miller, D., \& Dinan, W. (2003). Global public relations and global capitalism. In D. Demers (Ed.), Terrorism, globalization and mass communication (pp. 193-214). Spokane, WA: Marquette Books.

Molleda, J.-C., \& Ferguson, M. A. (2004). Public relations roles in Brazil: Hierarchy eclipses gender differences. Journal of Public Relations Research, 16(4), 327351.

Molleda, J. C., \& Moreno, A. (2008). Balancing public relations with socioeconomic and political environments in transition: comparative, contextualized research of Colombia, México and Venezuela. Journalism and Mass Communication Monographs, 10(2), 116-174.

Molleda, J.-C, \& Suárez, A. -M. (2005). Challenges in Colombia for public relation professionals: A qualitative assessment of the economic and political environments. Public Relations Review, 31, 21-29.

Moss, D., \& DeSanto, B. (2002). Public relations cases: International perspectives. New York: Routledge.

Müller, B. (1992). Standardization vs. specialization. An examination of Westernization in Japanese advertising. Journal of Advertising Research, 32(1), 15-24.

Nagashima, A. (1970). A comparison of Japanese and U. S. attitudes toward foreign products. Journal of Marketing, 34(1), 68-74.

Niemann-Struweg, I., \& Meintjes, C. (2008). The professionalism debate in South African public relations. Public Relations Review, 34, 224-229.

O'Neil, J. (2003). An analysis of the relationships among structure, influence, and gender: Helping to build a feminist theory of public relations. Journal of Public Relations Research, 15, 151-179.

Olins, W. (2002). Branding the nation - the historical context. Brand Management, 9(4-5), 241-248.

Pang, A., Jin, Y., \& Cameron, G. T. (2010). Contingency theory of strategic conflict management: Directions for practice of crisis communication from a decade of theory development, discovery, and dialogue. In W. T. Coombs, \& S. J. Holladay (Eds.), The handbook of crisis communication (pp. 527-549). Malden, MA: WileyBlackwell.

Pasquier, M., Weiss, R. M., \& Yersin, N. (2009). Das Image der Schweiz im Ausland, Mit Fallbeispiel China. Bern/Stuttgart/Wien: Verlag Haupt.

Passow, T., Fehlmann, R., \& Grahwohl, H. (2005). Country reputation - from measurement to management: The case of Liechtenstein. Corporate Reputation Review, 7(4), 309-326.

Pratt, C. (1985). Public Relations in the Third World. The African context. Public Relations Journal, 41(2), 11-12, 15-16.

Rhee, Y. (2002). Global public relations: A cross-cultural study of the excellence theory in South Korea. Journal of Public Relations Research, 14, 159-184.

Robertson, R. (1993). Globalization, social theory and global culture. London: Sage.

Ronneberger, F., \& Rühl, M. (1992). Theorie der Public Relations. Ein Entwurf. Wiesbaden: West-deutscher Verlag.

Röttger. U. (2005). Kommunikationsmanagement in der Dualität von Struktur. Die Strukturationstheorie als kommunikationswissenschaftliche Basistheorie. Medienwissenschaft Schweiz, 2, 12-19.

Sallot, L. M., Lyon, L. J., Acosta-Alzuru, C., \& Ogata Jones, K. (2003). From Aardvark to Zebra: A new millennium analysis of theory development in public relations academic journals. Journal of Public Relations Research, 15(1), 27-90.

Sandhu, S., \& Huck-Sandhu, S. (2013). Die internationale Visibilität der PRForschung im deutsch-sprachigen Raum. In D. Ingenhoff (Hrsg.), Internationale PR-Forschung (pp. 341-365). Konstanz: UVK Verlag.

Schmid, M., Seidenglanz, R., \& Westermann, A. (2013): Der Einfluss von Social Media auf die Dialogorientierung von Organisationskommunikation: Eine explorative Studie im europäischen Kontext. In D. Ingenhoff (Hrsg), Internationale PRForschung (pp. 137-157). Konstanz: UVK Verlag.
Schwarz, A. (2013). Internationale und komparative Krisenkommunikationsforschung: Relevanz, State of the Art und Forschungsagenda. In D. Ingenhoff (Hrsg.), Internationale PR-Forschung (pp. 261-289). Konstanz: UVK Verlag.

Sharp, M. (1992). The impact of social and cultural conditioning on global public relations. Public Relations Review, 18, 103-107.

Sievert, H., \& Porter, S. (2009). An expanded view from the corner office further discussions and research on the global navigation of international corporate communications. Retrieved from http://www.instituteforpr.org/ wp-content/uploads/Sievert_Porter.pdf (11.10.2012).

Signitzer, B., \& Coombs, T. (1992). Public relations and public diplomacy: Conceptua convergences. Public Relations Review, 18, 137-147.

Sriramesh, K. (1992). Societal culture and public relations: Ethnographic evidence from India. Public Relations Review, 18, 201-211.

Sriramesh, K. (1996). Power distance and public relations: An ethnographic study of Southern Indian organizations. In H. M. Culbertson, \& N. Chen (Eds.), International public relations. A comparative analysis (pp. 171-190). Mahwah, NJ: Lawrence Erlbaum.

Sriramesh, K. (2003). Introduction. In K. Sriramesh, \& D. Verčič (Eds.), The globa public relations handbook. Theory, research and practice (Vol. 1) (pp. xxv-xxxvi), Mahwah, NJ: Lawrence Erlbaum.

Sriramesh K. (2004). Epilogue: The need for more multiculturalism in public relations education in Asia. In K. Sriramesh (Ed.), Public relations in Asia: An anthology (pp. 321-341). Singapore: Thomson Learning.

Sriramesh, K., \& Verčič, D. (2001). International public relations: A framework for future research. Journal of Communication Management, 6(2), 103-117.

Sriramesh, K., \& Verčič, D. (2003). . The global public relations handbook. Theory, research and practice (Vol. 1) Mahwah, NJ: Lawrence Erlbaum Associates.

Sriramesh, K., \& Verčič, D. (2009a). A theoretical framework for global public relations research and practice. In K. Sriramesh, \& D. Verčič (Eds.), The global public relations handbook: Theory, research, and practice (pp. 3-21). New York: Routledge.

Sriramesh, K. \& Verčič, D. (Eds.). (2009b). The global public relations handbook, revised and expanded edition: Theory, research, and practice. New York/Abingdon: Routledge.

Sriramesh, K., Grunig, J. E.. \& Dozier, D. M. (1996). Observation and measurement of two dimensions of organizational culture and their relationship to public relations. Journal of Public Relations Research, 8(4), 229-261.

Sriramesh, K., Kim, Y., \& Takasaki, M. (1999). Public relations in three Asian cultures: An analysis. Journal of Public Relations Research, 11(4), 271-292.

Stevenson, N. (2000). Globalization and cultural political economy. In R. D. Germain (Ed.), Globalization and its critics. Perspectives from political economy (pp.91-116). London: Macmillan Press.

Stöhr, M. (2005). Die Strategie der standardisierten Differenzierung: Vorschläge für die strategische Ausrichtung internationaler PR. In C. Mast (Ed.), Internationale Unternehmenskommunikation. Ergebnisse einer qualitativen Befragung von Kommunikationsverantw ortlichen in 20 multinational Großunternehmen (pp. 53-63). Stuttgart: Lucius \& Lucius.

Süßmuth, H. (1994). Deutschlandbilder in Dänemark, England, in Frankreich und den Niederlanden. Baden-Baden: Nomos.

Szondi, G. (2005). The pantheon of international public relations for nation states: Country promotion in central and Eastern Europe. In R. Ławniczak (Ed.), Introducing market economy institutions and instruments: The role of public relations in transition economies (pp. 207-229). Poznań: Piar.

Szondi, G. (2009). International context of business relations. In R Tench, \& L Yeomans (Eds.), Exploring public relations (pp. 117-146). Harlow: Pearson.

Tak, J. (1999). Public Relations einer internationalen Organisation. Eine Fallstudie an Beispiel der Europäischen Union. Frankfurt am Main: Peter Lang/Europäischer Verlag der Wissenschaften.

Tayeb, M. (1988). Organizations and National culture: A comparative analysis. London: Sage.

Taylor, M. (2000). Cultural variance as a challenge to global public relations: A case study of the coca-cola scare in Europe. Public Relations Review, 26(3), 277-293.

Taylor, M. (2001). Internationalizing the public relations curriculum. Public Relations Review, 27, 73-88

Tilson, D. J., \& Alozie, E. C. (2004). Toward the common good. A global overview. In D. J. Tilson, \& E. C. Alozie (Eds.), Toward the common good. Perspectives in international public relations (pp. 1-12). Boston: Pearson.

Tyler, E. (1871). Primitive culture: Researches in the development of mythology, philosophy, religion, language, art, and custom. London: John Murray.

van Dyke, M. A. (2005). Toward a theory of just communication: A case study of NATO, multinational public relations, and ethical management of international conflict (Unpublished dissertation). University of Maryland, College Park.

van Leuven, J., \& Pratt, C. (1996). Public relations' role: Realities in Asia and in Africa South of the Sahara. In H. Culbertson \& N. Chen (Eds.). International public relations: A comparative analysis (pp. 93-106). Mahwah, NJ: Lawrence Erlbaum.

van Ruler, B., \& Verčič, D. (2004). . Public relations and communication management in Europe. A nation-by-nation introduction to public relations theory and practice (Vol. 1) Berlin, NY: Walter de Gruyter.

Vasquez, G., \& Taylor, M. (2000). What cultural values influence American public relations practitioners? Public Relations Review, 25(4), 433-449.

Verčič, D., Grunig. L. A. \& Grunig.J. E. (1996). Global and specific principles of public relations: Evidence from Slovenia. In H. M. Culbertson, \& N. Chen (Eds.) International public relations. A comparative analysis (pp. 31-65). Mahwah: Lawrence Erlbaum.

Vitiello, G. (2008). How host nations use the Olympics to Burnish their country's public image. Television Quarterly, 38(3-4), 45-50. 
Voss, K. (2007). Öffentlichkeitsarbeit von Nichtregierungsorganisationen: Mittel, Ziele, interne Strukturen. Wiesbaden: VS Verlag (1. Aufl. ed.)

Wakefield, R. I. (1997). International public relations: A theoretical approach to excellence based on a worldwide Delphi study (Dissertation). University of Maryland, College Park

Wakefield, R. I. (2000). World-class public relations: A model for effective public relations in the multinational. Journal of Communication Management, 5(1), 59-71.

Wakefield, R. I. (2007). A Retrospective on world class: the excellence theory goes international. In E. L. Toth (Ed.), The future of excellence in public relations and communication management. Challenges for the next generation (pp. 545-568). Mahwah NJ/London: Lawrence Erlbaum.

Wakefield, R.I. (2008). Theory of international public relations, the Internet, and activism: A personal reflection. Journal of Public Relations Research, 20,138-157.

Wilcox, D. L., Ault, P. H., \& Agee, W. K. (1989). Public relations. Strategies and tactics, New York: Harper \& Row.
Wouters, J. (1991). International public relations. New York: Amacom.

Wu, M.-Y. (2005). Can American public relations theories apply to Asian cultures? Public Relations Quarterly, (Fall), 23-27.

Wu, M.-Y., \& Baah-Boakye, K. (2007). A profile of public relations practice in Ghana: Practitioners' roles, most important skills for practitioners, relationship to marketing, and gender equality. Public Relations Quarterly, 52(1), 30-36.

Wu, M.-Y., Taylor, M., \& Chen, M.-J. (2001). Exploring societal and cultural influences on Taiwanese public relations. Public Relations Review, 27(3), 317 336.

Zaharna, R. S. (2000). Intercultural communication and international public relations: Exploring parallels. Communication Quarterly, 48(1), 85-100.

Zaharna, R.S. (2001). "In-awareness" approach to international public relations. Public Relations Review, 27, 135-148.

Zerfaß, A. (2004). Unternehmensführung und Öffentlichkeitsarbeit. Grundlegung einer Theorie der Unternehmenskommunikation und Public Relations. Wiesbaden: VS Verlag. 